\title{
Sea scallop mass mortality in a Marine Protected Area
}

\author{
Kevin D. E. Stokesbury ${ }^{1, *}$, Bradley P. Harris ${ }^{1}$, Michael C. Marino II ${ }^{1}$, \\ Jacob I. Nogueira ${ }^{2}$
}

${ }^{1}$ Department of Fisheries Oceanography, School for Marine Science and Technology, University of Massachusetts Dartmouth, and University of Massachusetts School of Marine Sciences, 838 South Rodney French Boulevard, New Bedford, Massachusetts 02744-1221, USA

${ }^{2}$ Hopkins Marine Station, Stanford University, 120 Oceanview Boulevard, Pacific Grove, California 93950, USA

\begin{abstract}
A mass mortality of the sea scallop Placopecten magellanicus occurred between 2004 and 2005 in the Nantucket Lightship Closed Area (NLCA), a Marine Protected Area (MPA) in the Great South Channel, USA. On a broad scale $\left(3951 \mathrm{~km}^{2}\right)$, scallop density (ind. $\mathrm{m}^{-2}$ ) in the MPA declined by $35 \%$. On a fine scale $\left(504 \mathrm{~km}^{2}\right)$, in the northeast corner of the MPA where most scallops occur, density declined by $50 \%$. The scallops that perished were large and probably old; $80 \%$ had shell heights $>130 \mathrm{~mm}\left(H_{\infty}=155 \mathrm{~mm}\right)$. Only $6 \%$ of the decline in the northeast corner was explained by fishing mortality. The mass mortality equaled approximately 6484 metric tons of harvestable scallop meat (equivalent to US $\$ 100$ million ex-vessel). Closing the NLCA to fishing in 1994 removed fishing mortality, increasing scallop survival rates. Scallops that recruited in 1994 reached $10 \mathrm{yr}$ of age in 2004. Individuals of this age may suffer the effects of senescence, including parasitism by shell borers and prokaryotic infection, which likely caused the mass mortality. If MPAs are used to manage fisheries, surveys with the accuracy and precision to resolve population dynamics on the spatial scale of the MPA are required or the benefits may be offset by increases in natural mortality.
\end{abstract}

KEY WORDS: Sea scallop $\cdot$ Placopecten magellanicus $\cdot$ Mass mortality $\cdot$ Video survey $\cdot$ Georges Bank $\cdot$ Marine Protected Area

\section{INTRODUCTION}

Marine Protected Areas (MPAs) are becoming a widely accepted management tool used to reduce fishing mortality and increase the long-term stability of fisheries (see reviews by Sanchez Lizaso et al. 2000, Hilborn et al. 2004, Sale et al. 2005). Benefits of reduced fishing pressure may include increases in density, size and age of protected populations.

Sea scallops are highly fecund, gonochoristic broadcast spawners with pelagic larvae, and abundances may increase dramatically when conditions favor reproduction and survival (Caddy 1989). Sea scallops are generally aggregated into clumps $\left(\mathrm{cm}^{2}\right)$, patches $\left(\mathrm{m}^{2}\right)$, beds $\left(\mathrm{km}^{2}\right)$ and grounds $\left(>10 \mathrm{~km}^{2}\right)$ (Brand 2006). Distribution and densities of sea scallops from clumps to beds are associated with sand/gravel substrate, low decapod and fish predation, and high abundances of filamentous fauna which often grow on sea scallop shells (Stokesbury \& Himmelman 1995, Henry \& Kenchington 2004). Grounds are associated with oceanographic conditions which facilitate larval retention (Tremblay et al. 1994).

The variability of the marine environment coupled with intense fishing pressure has resulted in a cyclic pattern of sea scallop abundance dominated by individual year-classes (Caddy 1989). Scallops on Georges Bank have been under consistent fishing pressure since the late 1800s, the only reprieve occurring during World War II (Serchuk et al. 1979). Scallop dredging was prohibited in 3 MPAs in 1994 to protect declining groundfish stocks, and scallop populations increased 


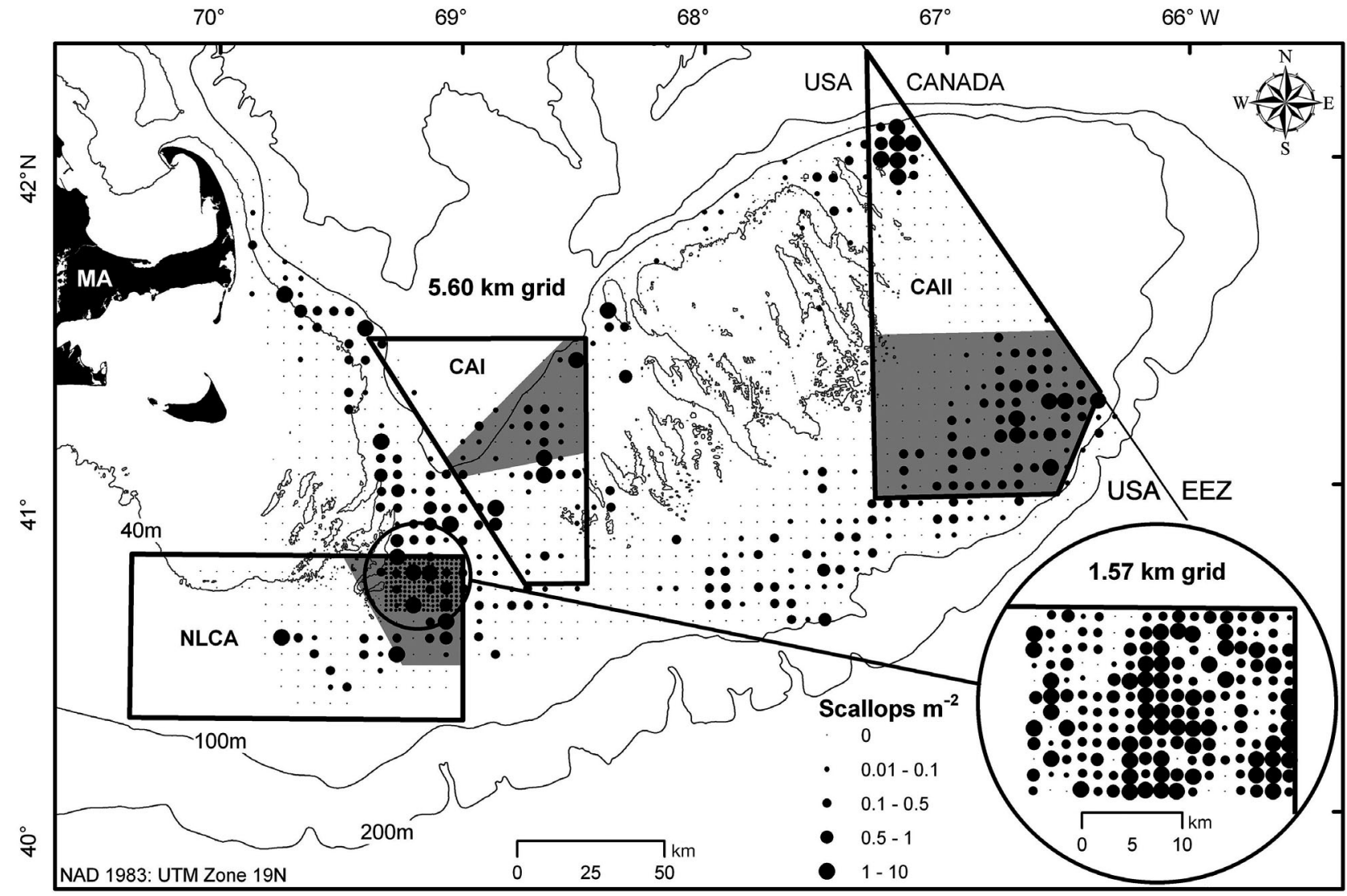

Fig. 1. Placopecten magellanicus. Sea scallop density $\left(\mathrm{m}^{-2}\right)$ from the 2004 video survey on the 5.60 and $1.57 \mathrm{~km}$ grids. Mass mortality occurred in the Nantucket Lightship Closed Area (NLCA) located southeast of Cape Cod, Massachusetts, USA. The other Georges Bank Marine Protected Areas, Closed Areas I (CAI) and II (CAII), are also shown. Limited sea scallop fishing was permitted in the Federal Fisheries Management Zones in 2000 and 2004 (grey shaded areas). EEZ: Exclusive Economic Zone

rapidly, reaching a biomass 9 times higher than those in the open areas after 4 yr of closure (Murawski et al. 2000, Stokesbury 2002, Stokesbury et al. 2004, Hart \& Rago 2006) (Fig. 1).

The Nantucket Lightship Closed Area (NLCA) is a $6167 \mathrm{~km}^{2}$ MPA in the Great South Channel (GSC) southeast of Cape Cod, Massachusetts, USA. It contains some of the highest densities of the sea scallop Placopecten magellanicus ever observed in the Georges Bank stock (mean $=1.67$ scallops $\mathrm{m}^{-2}, \mathrm{SE}=$ 0.254, harvestable biomass $=32465$ metric tons [t] of meat) (Stokesbury et al. 2004). Scallop density is highest in the northeast corner of the MPA (Fig. 1). To capitalize on this high density, a short-term fishery was permitted access and harvested $584 \mathrm{t}$ between 15 August and 31 October 2000 (Stokesbury \& Harris 2006). In 2004, fisheries managers adopted a formal rotational harvest strategy where short-term fisheries were permitted in Federal Fisheries Management Zones within the MPAs (NOAA 2004). Under this strategy, a second fishery in the NLCA harvested roughly 1134 t between 1 November 2004 and 31 January 2005 (A. Appelgate pers. comm.).
To evaluate the population dynamics of scallops in the NLCA MPA, we conducted annual video surveys. We hypothesized that scallop abundance in the NLCA would decline due to several factors: (1) a substantial proportion of the scallops were large and old (Stokesbury 2002, Stokesbury et al. 2004); (2) there was limited recruitment into the area (Stokesbury et al. 2004); (3) scallop abundance tends to fluctuate in a cyclic pattern (Dickie 1955, Caddy 1989); and (4) mass mortalities have occurred historically (Dickie \& Medcof 1963).

\section{MATERIALS AND METHODS}

We video surveyed scallop density in the NLCA using a centric systematic sampling design (Stokesbury 2002, Stokesbury et al. 2004). This survey design is flexible and the resolution of the sampling grid can be adjusted to accommodate desired precision or logistical limitations. From 1999 to 2002 and 2004 to 2006, 204 stations in the northeast corner of the NLCA were surveyed annually on a $1.57 \mathrm{~km}$ grid. These surveys covered $504 \mathrm{~km}^{2}$ and were designed for a precision of 
5 to $15 \%$ (Stokesbury 2002). From 2003 to 2006, 128 stations in the NLCA were surveyed annually on a $5.60 \mathrm{~km}$ grid. These surveys covered $3951 \mathrm{~km}^{2}$ and had a target precision of 15 to $30 \%$ (Stokesbury et al. 2004) (Fig. 1). We were unable to sample the NLCA in 2003 on the $1.57 \mathrm{~km}$ grid; however, the $5.60 \mathrm{~km}$ grid survey includes this area.

The surveys were conducted with a DeepSea multi SeaCam 2050 ${ }^{\circledR}$ underwater video camera mounted vertically on a pyramid, $1575 \mathrm{~mm}$ above the sea floor, providing a $3.24 \mathrm{~m}^{2}$ quadrat (Stokesbury et al. 2004). Four quadrats were sampled at each station, increasing the sample area to $12.94 \mathrm{~m}^{2}$. The time, depth, number of live and dead scallops, latitude and longitude were recorded at each station. After each survey the videotapes were reviewed in the laboratory and a still image of each quadrat was digitized. The field data were verified and the shell height $(\mathrm{mm})$ of each scallop was measured in the still image using Image Pro Plus ${ }^{\circledR}$ software.

Mean scallop density (ind. $\mathrm{m}^{-2}$ ) and SE were calculated for each survey using equations for a multi-stage sampling design (Cochran 1977, Stokesbury 2002). Scallop densities were compared between years with a $t$-test or, if the variance were heterogeneous, a Welch's approximate $t^{\prime}$-test (Zar 1996).

The absolute number of scallops within a survey area was calculated by multiplying scallop density by the total area surveyed (Stokesbury 2002). Estimates of scallop meat weight in grams $(w)$ were derived from shell height frequencies ( $S$ ) collected during each survey and a shell height to meat weight regression fit to data from dissections of live scallops $\left(n=103, r^{2}=0.91\right)$ collected during fishing trips in the NLCA between August and October 2000 (Stokesbury et al. 2004):

$$
W=1.21 \times 10^{-5} S^{3.1062}
$$

Mean $w$ was multiplied by the total number of scallops in the survey area to estimate the total biomass of scallop meats.

Two methods were used to calculate instantaneous natural mortality $(M)$. The first method (the 'clapper ratio') uses the ratio between the abundances (i.e. density) of clappers, shells of dead scallops still attached by the ligament $(D)$, and live scallops $(L)$ observed in the video survey, multiplied by the rate at which the shell ligament degrades (Merrill \& Posgay 1964):

$$
M_{\mathrm{c}}=\left(\frac{D}{L}\right)\left(\frac{52}{t}\right)
$$

where $52=$ number of ${\mathrm{wk} \mathrm{yr}^{-1}}^{-1}$ and $t=$ average number of weeks it takes for the 2 valves to separate, estimated as 33 wk on Georges Bank (Merrill \& Posgay 1964). This ratio produces a point estimate of instantaneous natural mortality $\left(M_{\mathrm{c}}\right)$ at the time of the survey (Dickie
1955). It assumes that clappers and live scallops are sampled equally. Further, this mortality estimate omits fish and crustacean predation where the shells are disarticulated (Stokesbury \& Himmelman 1995).

The second method produces an annual estimate of instantaneous natural mortality $\left(M_{\mathrm{a}}\right)$, which is the difference between the instantaneous total mortality $(Z)$ and the instantaneous fishing mortality $(F) . Z$ of recruited scallops observed by the video survey was calculated using (Beverton \& Holt 1957, Ricker 1975):

$$
Z=\ln \left(\frac{n_{0}}{n_{1}}\right) / \Delta t
$$

where $n_{0}=$ number of scallops greater than or equal to size at recruitment to the fishery (90 $\mathrm{mm}$ shell height) at the initial time $(t=0)$, and $n_{1}=$ number of scallops greater than or equal to $90 \mathrm{~mm}$ plus the growth increment estimated for the time (yr) between subsequent surveys $(\Delta t)$. The growth increment was estimated with the von Bertalanffy growth function (VBGF):

$$
H_{t}=H_{\infty}\left[1-\mathrm{e}^{-k\left(t-t_{0}\right)}\right]
$$

where $H_{t}(\mathrm{~mm})=$ scallop shell height at time $t(\mathrm{yr}), t_{0}=$ theoretical time when $\mathrm{H}$ is zero, and $k\left(\mathrm{yr}^{-1}\right)$ is the rate at which shell height approaches the mean asymptotic size $H_{\infty}(\mathrm{mm})$ (Beverton \& Holt 1957). We applied the VBGF parameters $H_{\infty}=155 \mathrm{~mm}, k=0.33 \mathrm{yr}^{-1}$ for the GSC and set $t_{0}=0.5 \mathrm{yr}$ to roughly correspond with initial shell growth after settlement in late autumn (Harris \& Stokesbury 2006). F was calculated using Baranov's catch equation (Ricker 1975) recast as:

$$
F=\frac{C Z}{n_{0}\left(1-\mathrm{e}^{-Z}\right)}
$$

where $C=$ number of scallops harvested.

The 2004 fishery harvested $1134 \mathrm{t}$ of scallop meats equaling 25 million scallops assuming a mean individual meat weight of $0.0458 \mathrm{~kg}$ (see Table 1). The mean meat weight was estimated using the shell heights observed in 2004 and the shell height meat weight regression collected in 2000 (our Eq. 1, Stokesbury et al. 2004).

We predicted the scallop shell height frequency in 2005 by applying growth to the shell height frequency observed in 2004. The density of scallops in each $10 \mathrm{~mm}$ bin was calculated by multiplying the fraction of scallops measured by the total observed and dividing by the area viewed (no. stns $\times 12.94 \mathrm{~m}^{2}$ ). The shell heights from 2004 were projected to the time of the 2005 survey using the VBGF parameters for GSC sea scallops and assumed no growth for scallops greater than the mean maximum asymptotic size, $H_{\infty}=155 \mathrm{~mm}$ (our Eq. 4, Harris \& Stokesbury 2006). We subtracted the observed scallop shell height frequency in 2005 from the predicted shell height frequency to estimate which sizes suffered the greatest mortality. 


\section{RESULTS}

Estimated mean scallop density significantly increased from 1999 to 2002 in the northeast corner of the NLCA (1.57 km grid) ( $t$-test $=-5.045, \mathrm{df}=406, \mathrm{p}<$ 0.001 ) and then remained constant from 2002 to 2004 $(t$-test $=-0.605, \mathrm{df}=406,2$-tailed $\mathrm{p}=0.545)($ Table 1 , Fig. 2). Mass mortality resulted in a $50 \%$ decline from $0.76( \pm 0.146 \mathrm{CI})$ to $0.38( \pm 0.098 \mathrm{CI})$ scallops $\mathrm{m}^{-2}$ $\left(t^{\prime}\right.$-test $=4.298, \mathrm{df}=355,2$-tailed $\left.\mathrm{p}<0.001\right)$ between 2004 and 2005 (Table 1, Fig. 2). Mean scallop density increased slightly, though not significantly, between 2005 and 2006 ( $t$-test $=-1.110, \mathrm{df}=405,2$-tailed $\mathrm{p}=$ 0.268) (Table 1, Fig. 2). The estimated biomass increased by $63 \%$ between 1999 and 2004 due to increases in density and average meat weight, then declined by $43 \%$ between 2004 and 2005 due to mass mortality, and increased by $12 \%$ from 2005 to 2006 (Table 1, Fig 2).

Based on abundance, $Z$ was $0.56 \mathrm{yr}^{-1}$ between the 2004 and 2005 surveys. Natural mortality accounted for most of the loss $\left(M_{\mathrm{a}}=0.47 \mathrm{yr}^{-1}\right)$, while fishing mortality accounted for very little $\left(F=0.09 \mathrm{yr}^{-1}\right)$ (Table 2). Little evidence of the mass mortality was provided by $Z$ based on the clapper ratio $\left(M_{\mathrm{c}}\right)$ estimated at $0.03 \mathrm{yr}^{-1}$ in May 2004, and $0.04 \mathrm{yr}^{-1}$ in October 2005 (Table 3).

Estimated mean scallop density measured in the $5.60 \mathrm{~km}$ grid survey decreased by $55 \%$ between 2003 and 2005 (Fig. 2). Although this decline agrees with the $1.57 \mathrm{~km}$ grid survey, it was not significant $\left(t^{\prime}\right.$-test $=$ $1.084, \mathrm{df}=185,2$-tailed $\mathrm{p}=0.280$ ). Between 2005 and 2006 mean scallop density increased slightly, though not significantly $(t$-test $=-1.243, \mathrm{df}=254,2$-tailed $\mathrm{p}=$ 0.215) (Table 1, Fig. 2). The $5.60 \mathrm{~km}$ grid survey cov-

Table 1. Placopecten magellanicus. Mean sea scallop density (scallops $\mathrm{m}^{-2}$ ) using a multi-stage sampling design. Average meat weight $(w, g)$, estimated from shell height frequencies observed during each survey, and the 2000 shell height meat weight regression were used to estimate the metric tons ( $t$ ) of meat weight in each area

\begin{tabular}{|c|c|c|c|c|c|c|}
\hline \multirow[t]{2}{*}{ Year } & \multicolumn{3}{|c|}{ Scallops } & \multirow{2}{*}{$\begin{array}{c}\text { Average } \\
\qquad W\end{array}$} & \multirow{2}{*}{$\begin{array}{l}\text { No. of scallops } \\
\qquad\left(\times 10^{6}\right)\end{array}$} & \multirow{2}{*}{$\begin{array}{c}\text { Total } \\
W\end{array}$} \\
\hline & $\mathrm{m}^{-2}$ & $\mathrm{SE}$ & $\mathrm{CV}$ & & & \\
\hline \multicolumn{7}{|c|}{$1.57 \mathrm{~km}$ grid (area surveyed $=504 \mathrm{~km}^{2}$ ) } \\
\hline 1999 & 0.38 & 0.057 & 14.9 & 34.2 & 194 & 6625 \\
\hline 2000 & 0.40 & 0.033 & 8.2 & 37.8 & 201 & 7611 \\
\hline 2001 & 0.62 & 0.057 & 9.3 & 34.2 & 311 & 10640 \\
\hline 2002 & 0.82 & 0.066 & 8.1 & 41.8 & 413 & 17265 \\
\hline 2004 & 0.76 & 0.074 & 9.7 & 45.8 & 386 & 17700 \\
\hline 2005 & 0.38 & 0.050 & 13.1 & 52.4 & 192 & 10082 \\
\hline 2006 & 0.46 & 0.047 & 10.3 & 49.2 & 232 & 9003 \\
\hline \multicolumn{7}{|c|}{$5.6 \mathrm{~km}$ grid $\left(\right.$ area surveyed $=3951 \mathrm{~km}^{2}$ ) } \\
\hline 2003 & 0.21 & 0.040 & 19.4 & 33.0 & 816 & 26956 \\
\hline 2004 & 0.16 & 0.047 & 29.1 & 44.3 & 637 & 28922 \\
\hline 2005 & 0.10 & 0.023 & 22.1 & 52.4 & 414 & 21700 \\
\hline 2006 & 0.15 & 0.033 & 22.9 & 43.6 & 577 & 25154 \\
\hline
\end{tabular}

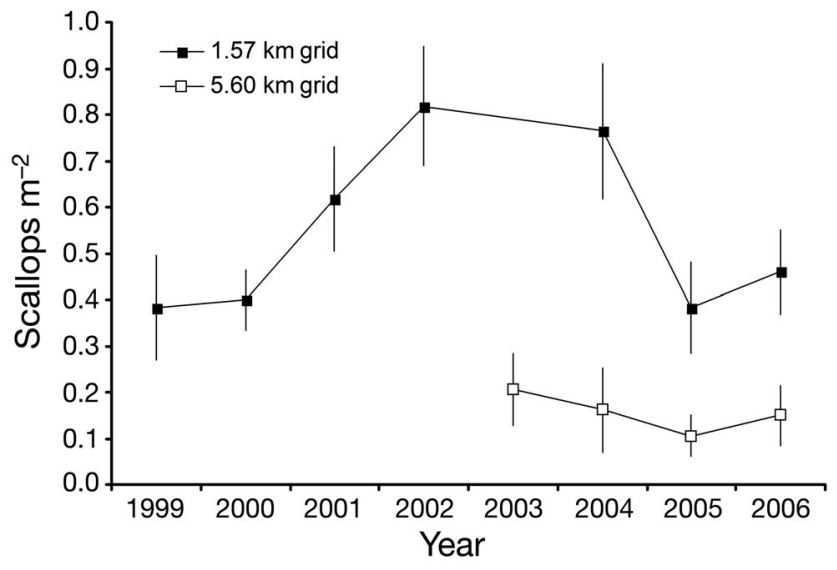

Fig. 2. Placopecten magellanicus. Average sea scallop densities (error bars: $\pm 95 \%$ CI) in the NLCA surveyed from 1999 to 2002 and 2004 to 2006 on a $1.57 \mathrm{~km}$ grid and from 2003 to 2006 on a $5.60 \mathrm{~km}$ grid

Table 2. Placopecten magellanicus. Instantaneous natural mortality $\left(M_{a}\right)$ and fishing mortality $(F)$ were estimated from the 2004 and 2005 video surveys on the fine $(1.57 \mathrm{~km})$ and broad $(5.60 \mathrm{~km})$ scale grids. $\mathrm{CI}= \pm 95 \% ; \Delta t$ : time lapsed between surveys (yr) (see Eq. 3)

\begin{tabular}{|rrrrrrrr}
\hline $\begin{array}{r}\text { Grid } \\
(\mathrm{km})\end{array}$ & \multicolumn{2}{c}{$2004-$} & \multicolumn{2}{c}{$2005-$} & $\Delta t$ & $F$ & $M_{\mathrm{a}}$ \\
\hline 1.57 & 352 & 67.4 & 159 & 44.3 & 1.42 & 0.09 & 0.47 \\
5.60 & 564 & 356.3 & 348 & 196.0 & 0.95 & 0.06 & 0.45 \\
\end{tabular}

ered more area and contained large regions with no scallops, resulting in density estimates with lower precision. The estimated biomass increased by $7 \%$ between 2003 and 2004, decreased by $25 \%$ between 2004 and 2005, and increased again by $14 \%$ between the 2005 and 2006 surveys (Table 1).

$M_{\mathrm{a}}$ estimated for the $5.60 \mathrm{~km}$ grid survey between 2004 and 2005 was similar to that of the $1.57 \mathrm{~km}$ survey (0.45 and $0.47 \mathrm{yr}^{-1}$, respectively) (Table 2). The estimate of $M_{c}$ in August 2004 was higher $\left(0.18 \mathrm{yr}^{-1}\right)$ than any other survey (Table 3 ). In May and June 2005, $M_{\mathrm{c}}$ was $0.04 \mathrm{yr}^{-1}$, equivalent to the estimate from the $1.57 \mathrm{~km}$ grid survey in October 2005 (Table 3).

The scallops were very large in the northeastern corner of the NLCA; $10.0,15.5$, and $14.1 \%$ were greater than $H_{\infty}=155 \mathrm{~mm}$ in 2004, 2005, and 2006 respectively, compared to $2.3 \%$ in 1999 (Fig. 3). Of the scallops that 
Table 3. Placopecten magellanicus. Natural mortality $\left(M_{\mathrm{c}}\right)$ estimated from the ratio of the abundance (ind. $\times 10^{6}$ ) of clappers to live sea scallops (Eq. 2). CI $= \pm 95 \%$

\begin{tabular}{|c|c|c|c|c|c|c|}
\hline & $\operatorname{Grid}(\mathrm{km})$ & Clappers & S CI & Scallops & $\mathrm{CI}$ & $M_{\mathrm{c}}$ \\
\hline \multicolumn{7}{|l|}{2004} \\
\hline May & 1.57 & 8 & 2.8 & 385 & 73.7 & 0.034 \\
\hline Aug & 5.60 & 67 & 36.1 & 584 & 336.6 & 0.180 \\
\hline \multicolumn{7}{|l|}{2005} \\
\hline Oct & 1.57 & 5 & 3.7 & 192 & 49.7 & 0.040 \\
\hline May-Jun & n 5.60 & 10 & 9.3 & 413 & 180.8 & 0.040 \\
\hline
\end{tabular}

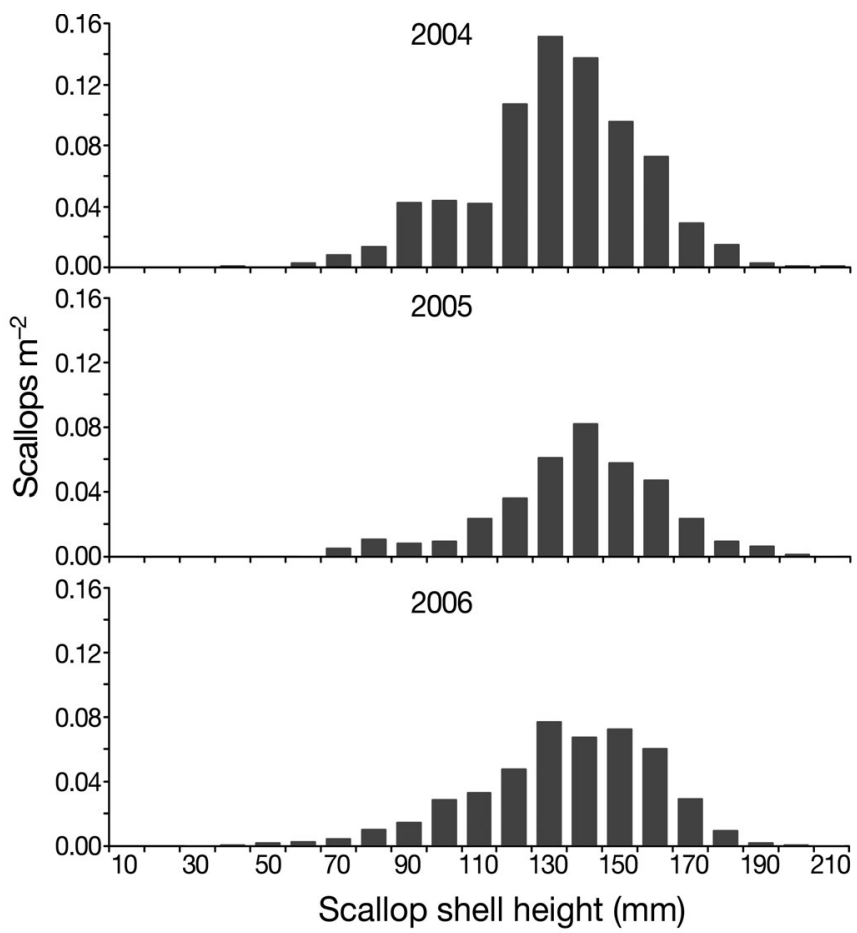

Fig. 3. Placopecten magellanicus. Sea scallop shell height frequencies $(\mathrm{mm})$ sampled in the northeast corner $(1.57 \mathrm{~km}$ grid) of the NLCA from 2004 to 2006

perished, $80 \%$ had a shell height greater than $130 \mathrm{~mm}$ (Fig. 4).

\section{DISCUSSION}

A mass mortality of sea scallops occurred in the NLCA between 2004 and 2005. The population of scallops within the $3951 \mathrm{~km}^{2}$ survey area declined by $35 \%$. Half the scallops died in the dense aggregation located in the northeast corner $\left(504 \mathrm{~km}^{2}\right)$. The scallops that perished were large and old. The increase in the number of clappers between May and August 2004 sug- gested that a large portion of the mortality occurred at that time. The loss in the NLCA MPA was approximately $6484 \mathrm{t}$ of harvestable scallop meat, worth about US \$100 million (ex-vessel).

Marine bivalve populations suffer natural mortality from many sources, including abiotic agents (such as temperature, aerial exposure, salinity, oxygen concentration, siltation, burial by shifting sediment, and direct movement to unfavorable habitats by current) and biotic agents (primarily predation, parasitism, and disease). Several of these factors occurring in concert, or a catastrophic event such as a storm, widespread anoxia or a disease epidemic, may result in mass mortalities (Dame 1996).

The scallops in the northeastern corner of the NLCA occur at 40 to $100 \mathrm{~m}$ depth. Therefore, many of the abiotic agents that cause mass mortalities in the intertidal or subtidal zones are unlikely to influence this aggregation. In the Gulf of St. Lawrence, the largest mass mortality events, where up to $80 \%$ of the sea scallops died, were caused by wind-induced conditions exposing sea scallops to lethal water temperatures of about $20^{\circ} \mathrm{C}$ between 1928 and 1950 (Dickie \& Medcof 1963). However, extreme temperature fluctuations are unlikely in the NLCA where tidal currents are strong and the water column is well mixed (Merrill \& Posgay 1964, Butman \& Beardsley 1987).

Tidally induced bottom currents can be strong in the NLCA (exceeding $30 \mathrm{~cm} \mathrm{~s}^{-1}$ ) and storm events are common during winter months (Brown \& Moody 1987 , Butman \& Beardsley 1987). High flow from tides and storms, which moves sea scallops and sediment, caus-

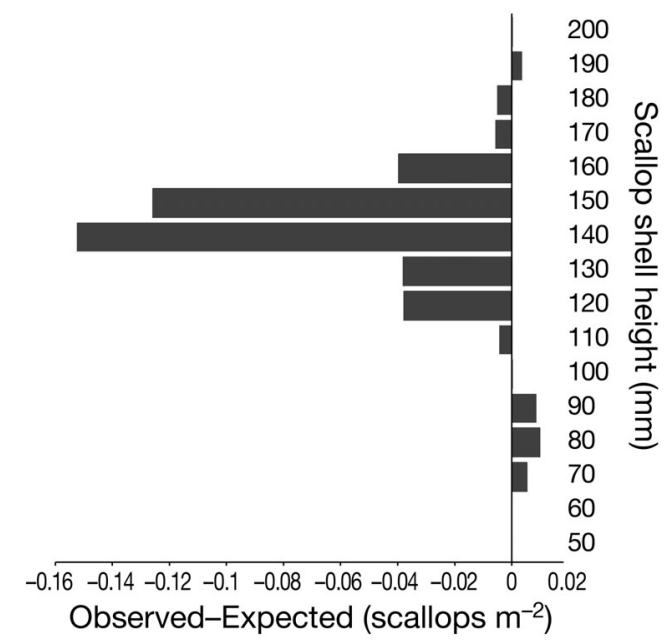

Fig. 4. Placopecten magellanicus. Frequency of the difference in sea scallop shell heights $(\mathrm{mm})$ between the expected values using the 2004 shell height distributions of the von Bertalanffy growth function and the observed 2005 shell height frequencies. Positive bars indicate an increase, while negative bars indicate a loss in the number of scallops for each shell height bin 
ing piling and burial, may result in mortality (Grant et al. 1993). Over half of the granule/pebble sediment observed in 1999 was covered by sand in 2000 (Stokesbury \& Harris 2006). However, no extreme storm events occurred between the May 2004 and October 2005 surveys; the strongest storm was a Beaufort force 8-9 gale occurring on 27 December 2004 (NOAA National Data Buoy \#44008).

Predation, primarily by sea stars, has resulted in smaller mass mortalities; for example, up to $25 \%$ of the sea scallops within an aggregation were preyed on by sea stars in the Gulf of St. Lawrence (Dickie \& Medcof 1963). A high concentration of sea stars preying on sea scallops may be responsible for a large decrease in sea scallop density in the southern portion of Closed Area II in 2003 (Stokesbury et al. 2004). However, sea star predation is limited by prey size (Barbeau et al. 1994), and although there were high concentrations of sea stars in the NLCA during 2004 and 2005, the sea stars were too small to cause the mass mortality of the larger scallops (mean arm length in $2004=23.7 \mathrm{~mm}, \mathrm{SE}=$ 0.26, authors' unpubl. data). Further, no active sea star predation was observed in the 2004 or 2005 surveys.

Between 1 November 2004 and 31 January 2005, commercial scallopers fishing in the NLCA reported catches and provided samples of scallops infested with boring sponges Cliona vastifica and polycheate worms Polydora sp. These parasites weaken the shells of scallops, making them more vulnerable to predation (Evans 1969, Bergman et al. 1982). Scallopers also reported areas in the northeast corner of the NLCA where the meat of large scallops was so small, stringy in texture, and gray that it was unmarketable. Grayishbrown tinged, flaccid, stringy meat in scallops may be caused by clionid infestation or prokaryotic infection (Medcof 1949, Gulka et al. 1983). Small, stringy, gray meat occurs primarily in large, old scallops; Stevenson (1936) related these conditions to senescence in Bay of Fundy sea scallops, while Medcof (1949) noted that large, old scallops of approximately 8 or $9 \mathrm{yr}$ of age, $>135 \mathrm{~mm}$ shell height, had sufficient clionid parasitism to cause this meat condition in the Gulf of St. Lawrence. Prokaryotic infection caused similar meat conditions and a mass mortality of $73 \%$ of sea scallops, of varying sizes, in Narragansett Bay, Rhode Island (Gulka et al. 1983). The synergistic effect of senescence, parasitism by shell borers, and prokaryotic infection likely caused the 2004-2005 NLCA scallop mass mortality.

Spatially and temporally specific fisheries management tools, including MPAs, require new population assessment techniques. Traditional fisheries surveys use time series with low spatial resolution producing relative catch per unit effort (CPUE) estimates. The annual National Marine Fisheries Service (NMFS) scallop dredge survey on Georges Bank uses a stratified random design and produces CPUE estimates in units of meat weight (kg) per tow (Hart \& Rago 2006, Orensanz et al. 2006). NMFS observed a decline in the mean scallop density in the NLCA between 2004 and 2005. However, this decline cannot be interpreted as a decline in scallop abundance due to the small number of survey stations and high catch variability in the area (D. Hart pers. comm.). Further, growth increases biomass and may obscure changes in numbers if scallops are not individually counted.

We selected a survey method designed to obtain absolute estimates of scallop density at spatial and temporal scales congruent with the NLCA MPA. However, the precision of the $5.60 \mathrm{~km}$ grid survey was still too low to detect a significant difference in the scallop densities before and after the mass mortality. Using the $1.57 \mathrm{~km}$ grid survey we estimated an instantaneous natural mortality of $0.47 \mathrm{yr}^{-1}$ equal to an annual rate of $38 \%$. This estimate captures the mass mortality and is approximately 5 times higher than the instantaneous natural mortality rate of $0.10 \mathrm{yr}^{-1}$ assumed by fisheries managers (Serchuk et al. 1979, Caddy 1989, Hart \& Rago 2006).

Estimates of natural mortality have a strong influence on USA sea scallop fisheries management, which employs a yield-per-recruit model. Among the parameters used to calculate the yield-per-recruit curve, variations in natural mortality $(M)$ are likely to influence the shape of the curve more than any other (Beverton \& Holt 1957). The estimate of $M=0.10 \mathrm{yr}^{-1}$ is based on stock-wide data from a heavily fished population where few scallops reached a large size and old age. It is assumed to represent scallops in specific areas, which may contain high densities and large individuals (Hart 2003). Taking into account the potential for mass mortalities may reduce the maximum yield-per-recruit increasing the corresponding fishing mortality $\left(F_{\max }\right)$ (Beverton \& Holt 1957).

Closing the NLCA to fishing resulted in increased scallop survival rates: scallops that recruited in 1994 reached at least $10 \mathrm{yr}$ of age in 2004 . However, as we hypothesized, sea scallops suffered a mass mortality between 2004 and 2005 with a $35 \%$ decline in overall density and a $50 \%$ decline in the northeast corner of the MPA. The majority of scallops that perished were large, suggesting advanced age, and may have suffered effects of senescence, including infestation by boring sponges Cliona vastifica and polycheate worms Polydora sp., and prokaryotic infection.

MPAs are viewed as an insurance policy against stochastic and unforeseen events associated with the uncertainty surrounding fisheries management strategies. However, resource availability, recruitment, 
inter- and intraspecific interactions, and space will determine the maximum size a population can reach in a MPA (Sanchez Lizaso et al. 2000). When these factors become limiting, increased natural mortality or emigration will dampen population growth (Sanchez Lizaso et al. 2000). Although sea scallops can swim short distances, they do not migrate (Posgay 1981, Stokesbury \& Himmelman 1996). Removal or reduction of fishing effort in MPAs may lead to rebuilding of sea scallop stocks, but the resource cannot be guaranteed indefinitely, and natural mortality must be considered and monitored (Hilborn et al. 2004). Our research underscores the need for surveys with the accuracy and precision to resolve population dynamics on the spatial scale of the MPA (in this case 10s to 1000s of $\mathrm{km}^{2}$ ).

Acknowledgements. We thank B. J. Rothschild for his support and guidance. We thank the owners, Captains, and crews who sailed with us. P. Christopher, D. Frie, R. Silva (NMFS) and L. Gavlin (USCG) provided the Letters of Authorization and insured smooth transitions between fishing and surveying for the vessels. T. Jaffarian and 3 anonymous reviewers provided helpful comments on the manuscript. Aid was provided by SMAST, the Massachusetts Division of Marine Fisheries, NOAA awards: NA16FM1031, NA06FM1001, NA16FM2416, NA04NMF4720332, NA04NMF4721131 and NA05NMF4540012, and the sea scallop fishery and supporting industries. The views expressed herein are those of the authors and do not necessarily reflect the views of NOAA or any other agencies.

\section{LITERATURE CITED}

Barbeau MA, Scheibling RE, Hatcher BG, Taylor LH, Hennigar AW (1994) Survival analysis of tethered juvenile sea scallops Placopecten magellanicus in field experiments: effects of predators, scallop size and density, site and season. Mar Ecol Prog Ser 115:243-256

Bergman KM, Elner RW, Risk MJ (1982) The influence of Polydora websteri boring on the strength of the shell of the sea scallop, Placopecten magellanicus. Can J Zool 60: 2551-2556

Beverton RJH, Holt SJ (1957) On the dynamics of exploited fish populations, Vol 19. United Kingdom Ministry of Agriculture, Fisheries and Food, London

Brand AR (2006) Scallop ecology: distributions and behaviour. In: Shumway SE, Parson GJ (eds) Scallops: biology, ecology and aquaculture. Elsevier, Amsterdam, p 651-744

Brown WS, Moody JA (1987) Tides. In: Backus RH (ed) Georges Bank. MIT Press, Cambridge, MA, p 100-107

Butman B, Beardsley RC (1987) Long-term observations on the southern flank of Georges Bank. Part I: A description of the seasonal cycle of currents, temperature, stratification, and wind stress. J Phys Oceanogr 17:367-384

Caddy JF (1989) A perspective on the population dynamics and assessment of scallop fisheries, with special reference to sea scallop, Placopecten magellanicus (Gmelin). In: Caddy JF (ed) Marine invertebrate fisheries: their assessment and management. John Wiley \& Sons, New York, p 559-589
Cochran WG (1977) Sampling techniques. John Wiley \& Sons, New York

Dame RF (1996) Ecology of marine bivalves: an ecosystem approach. CRC Press, Boca Raton, FL

Dickie LM (1955) Fluctuations on the abundance of the giant scallop Placopeten magellanicus (Gmelin) in Digby area of the Bay of Fundy. J Fish Res Board Can 12:797-857

Dickie LM, Medcof JC (1963) Cause of mass mortalities of scallops (Placopecten magellanicus) in the southwestern Gulf of St. Lawrence. J Fish Res Board Can 20(2):451-482

Evans JW (1969) Borers in the shell of sea scallop, Placopecten magellanicus. Am Zool 9:775-782

Grant J, Emerson CW, Shumway SE (1993) Orientation, passive transport, and sediment erosion features of the sea scallop Placopecten magellanicus in the benthic boundary layer. Can J Zool 71:953-959

Gulka G, Chang PW, Marti KA (1983) Prokaryotic infection associated with a mass mortality of the sea scallop, Placopecten magellanicus. J Fish Dis 6:355-364

Harris BP, Stokesbury KDE (2006) Shell growth of sea scallops (Placopecten magellanicus) in the southern and northern Great South Channel, USA. ICES J Mar Sci 63:811-821

Hart DR (2003) Yield- and biomass-per-recruit analysis for rotational fisheries, with an application to the Atlantic sea scallop Placopecten magellanicus. Fish Bull 101:44-57

Hart DR, Rago PJ (2006) Long-term dynamics of US Atlantic sea scallop Placopecten magellanicus populations. North Am J Fish Manag 26:490-501

Henry L, Kenchington E (2004) Differences between epilithic and epizoic hydroid assemblages from commercial scallop grounds in the Bay of Fundy, northwest Atlantic. Mar Ecol Prog Ser 266:123-134

Hilborn R, Stokes K, Maguire JJ, Smith T and 13 others (2004) When can marine reserves improve fisheries management? Ocean Coast Manag 47:197-205

Medcof JC (1949) Dark-meat and the shell disease of scallops. Prog Rep Atlantic Coast Stations 45:3-6

Merrill AS, Posgay JA (1964) Estimating the natural mortality rate of sea scallop (Placopecten magellanicus). Int Comm NW Atl Fish Res Bull 1:88-106

Murawski SA, Brown R, Lai HL, Rago PJ, Hendrickson L (2000) Large-scale closed areas as a fishery-management tool in temperate marine ecosystems: the Georges Bank experience. Bull Mar Sci 66:775-798

NOAA (2004) 15 CFR Part 902 and 50 CFR Part 648; Fisheries of the northeastern United States; Atlantic sea scallop fishery; Amendment 10; final rule. US Fed Reg 69(120):3519435224

Orensanz JM, Parma AM, Turk T, Valero J (2006) Dynamics, assessment and management of exploited natural populations. In: Shumway SE, Parsons GJ (eds) Scallops: biology, ecology and aquaculture. Elsevier B.V., Amsterdam, p 765-868

Posgay JA (1981) Movement of tagged sea scallops on Georges Bank. Mar Fish Rev 43:19-25

Ricker WE (1975) Computation and interpretation of biological statistics of fish populations. Bull Fish Res Board Can 191:1-382

Sale PF, Cowen RK, Danilowicz BS, Jones GP and 7 others (2005) Critical science gaps impede use of no-take fishery reserves. Trends Ecol Evol 20:75-80

Sanchez Lizaso J, Goni R, Renones O, Garcia Charton J and 5 others (2000) Density dependence in marine protected populations: a review. Environ Conserv 27:144-158

Serchuk FM, Wood PW, Posgay JA, Brown BE (1979) Assessment and status of sea scallop (Placopecten magellanicus) populations off the northeast coast of the United States. Proc Natl Shellfish Assoc 69:161-191 
Stevenson JA (1936) The Canadian scallop: its fishery, lifehistory and some environmental relationships. MSc thesis, University of Western Ontario, Waterloo

Stokesbury KDE (2002) Estimation of sea scallop abundance in closed areas of Georges Bank, USA. Trans Am Fish Soc 131:1081-1092

Stokesbury KDE, Harris BP (2006) Impact of limited shortterm sea scallop fishery on epibenthic community of Georges Bank closed areas. Mar Ecol Prog Ser 307:85-100

Stokesbury KDE, Himmelman JH (1995) Biological and physical variables associated with aggregations of the giant scallop Placopecten magellanicus. Can J Fish Aquat Sci 52:743-753

Editorial responsibility: Howard Browman (Associate Editorin-Chief), Storebø, Norway
Stokesbury KDE, Himmelman JH (1996) Experimental examination of movement of the giant scallop, Placopecten magellanicus. Mar Biol 124:651-660

Stokesbury KDE, Harris BP, Marino MC II, Nogueira JI (2004) Estimation of sea scallop abundance using a video survey in off-shore USA waters. J Shellfish Res 23:33-44

Tremblay M, Loder J, Werner F, Naimie C, Page F, Sinclair M (1994) Drift of sea scallop larvae Placopecten magellanicus on Georges Bank: a model study of roles of mean advection, larval behavior and larval origin. Deep-Sea Res $41: 7-79$

Zar JH (1996) Biostatistical analysis. Prentice Hall, Upper Saddle River, NJ

Submitted: December 5, 2006; Accepted: June 19, 2007 Proofs received from author(s): October 31, 2007 